\title{
Metropolitan Areas in their Evolutionary Progress, from Legal Standard to their Origins
}

\author{
Antonino Destefano ${ }^{1, a}$, Maria Ferrara ${ }^{1, b}$
}

\author{
${ }^{1}$ Mediterranea University of Reggio Calabria - PAU - Department of Heritage, Architecture, Urban \\ Planning, Via Salita Melissari - 89124, Reggio di Calabria, Italy \\ aantoninodestefano@gmail.com, ${ }^{b}$ maria.ferrara@unirc.it
}

Keywords: Metropolitan City, Regulation, Plan, Evolutionary Progress.

\begin{abstract}
This paper makes a point on a hypothetical research about the origins of metropolitan thought referring both to a natural process and to the need of reorganizing the concept of city focusing on its dimension and function. The metropolitan area originates from the evolution of built-up areas cut off by free spaces - between cities and rural villages - which preserve their municipal administrative autonomy (urban continuum). Since then the standards to define metropolitan areas have undergone different alterations. Initially the Italian law intervenes by reorganizing competences among administrative levels, afterwards by promulgating special founding laws. What kind of phenomenon is it and how can it be handled at a juridical level? What are its implications?
\end{abstract}

\section{The origins of metropolitan thought}

An article of «New England Gazetteer» of 1846 mentions the need to reorganize the concept of city considering its size, since the phenomenon of urban growth was concerning a number of cities. The presence of dominant cities, by virtue of their surface and size, was already proved even before 6.000 B.C.: in different areas of the globe there is evidence of ancient and big cities (Egypt, Mesopotamia, China).

Some scholars trace the origins of the word 'Metropolitan Areas' back to the early 1900s in North America, as a definition of conurbation. Others situate its origins in the United States (metropolis distrectis) meaning those urban areas with at least 20.000 inhabitants, characterized by a high population density, provided with an administration system, and also registered as 'central cities' referring to $15 \%$ commuting rate as well as to the presence of $25 \%$ of agricultural workers within the entire resident population.

The metropolitan area originates from the evolution of built-up areas cut off by free spaces between cities and rural villages - which preserve their municipal administrative autonomy (urban continuum). Since then the standards to define metropolitan areas have undergone different alterations, so much so that around the 1950s the surrounding areas (standard metropolitan statistical area) could be included in the heart of the city, provided that they had a population of at least 100.000 inhabitants and that the central city formed a functional agglomeration with the smallest cities (townships).

In Great Britain the geographers C. Bungay Fawcett (C. Bungay Fawcett, 1918) and T. W. Freeman intended the conurbation as a contiguous built-up area, with a population of 250.000 inhabitants, also introducing the concept of metropolitan counties and identifying 89 "minor conurbations".

In France, E. Benard and P. Vincent introduced the concepts of «isolated city» and «urban unity» referring to a municipality district or to a group of municipalities where over $50 \%$ of the population resides in a built-up area. Another condition is that they may all constitute an urban aggregation, the concept of urban unity being also used to identify each municipality and calculate the incidence of urban population. The central city, the core of urban unity, is considered as one if it reaches by itself over $50 \%$ of the total population. 
"Agglomerationsraum" is the basic concept in Germany: it refers to an urban area made up of a central city and a strip of suburban municipalities with a high population density.

In Italy, the geographer A. Sestini [1] started dealing with conurbation, referring to urban areas characterized by building contiguity and a high population density. As time passes other authors will continue using these terms from an economic, social, political and geographical point of view as well as with reference to services.

Before identifying the metropolitan area and its requirements, it is essential to focus on the concept of "city" meant as a portion of territory with a high settlement density and characterized by an intense and compact development around the existing old city. A wider area surrounding the city is the result of productive and residential expansion of the city in the neighbouring territories.

In some cases, big urban areas stretch as far as the nearest cities, intersecting large country sections and big urbanized systems, known as «metropolitan areas». The concept of conurbation, in the meaning of union of cities - conurbation (cum+urbis) - was coined by Patrick Geddes, Scottish town planner who compares conurbation to an octopus; the most glaring example of this is the city of London which swallowed up entire villages.

As we have seen, the metropolitan phenomenon has not gained ground only in Italy but it has taken root all over the world. It results not only from the need of wider urban facilities but above all from interrelation and interdependence relationships among the different functions and activities within it. They may even disclose some individuality inside, even though they are dominated by a city placing itself in the thick of the metropolitan process.

The interaction of services and residences involves different social actors that may be individual and collective or public and private; it generates flows of people between the area and the rest of the territory, also turning into a concentration in the metropolitan area of functions and subjects linked to strategic activities and system of coordination, and it is considered as coinciding with the territory of the Provincial administration (Bruzzo, Ferri, 2008) [2]. It must be underlined that the phenomenon of commuting is particularly important as well as the migration flows constituting the new deteriorating areas. Decadent districts give shelter to hundreds of immigrants who can create entire districts in a couple of days, generally concentrated on the edge of the metropolis. Most of these settlements, nearly always erected without planning permission, do not have high rents. It is really impossible for the local government to control this phenomenon, even as far as town planning and services are concerned, also due to the consequent financial modifications. As it was already specified, the area implies the presence of a big city which is the administrative seat (offices, etc.), and which houses Schools, Universities and Services (industries, banks, commercial facilities).

\section{A question of regulation}

From a juridical point of view, thanks to the establishment of the Ministry of Urban Areas in 1978, some major innovations were introduced in Italy. Due to direct elections of mayors and Province Governors, Law n. 142/1990 decentralized a large number of competences and functions, implementing a strong connection between the administrative action and the production of local policies. The focus is on tricky matters and on the establishment of new local governments, due to the outstanding urgent issues, to the new phenomena and problems which can no longer be ignored; the concept of metropolitan area may be linked to the image of an institutional entity absorbing a few municipalities' powers, even though not all of them.

The metropolitan area itself is envisaged as an individual context, a privileged place thanks to innovation processes. Thus, the administration of metropolitan areas turns out to be very complex and hard-won. This is ascribable to an unsuccessful cooperation among the different authorities, characterized by public and private actors' overlapping at local and central level of administration.

The reforms themselves have not firmly solved the problem which is, in the case of metropolitan areas, particularly evident in the powers and in the real relationships among the different levels of town planning. 
The causes of the difficulties that governments in large cities must face are to be found in the overlapping of powers and competences of metropolitan governments, regions and State and in the convoluted co-decision processes concerning these levels. Large cities are conceived as areas within which their inhabitants' sphere of life has two dimensions at the same time: a wider local dimension where there is an increasing demand, and a metropolitan dimension for the inhabitants outside the chief town who maintain daily relations. In fact, in large cities, which, despite their halt to the population growth, continue to occupy a growing land surface, there is a vast presence of derelict areas or areas waiting for land-use destination. The bad conditions of these lands often result both from heterogeneous growth and horizontal urbanization processes, known as urban sprawl. Today, city policies and projects have to take account of this, in order to reinterpret abandoned areas.

If, on the one hand, the reforms of the 1990s (concerning the Reorganization of local Authorities) probably produced cleverer administrators as well as more fluid relations with the citizens, on the other hand they did not tackle the problem for good, among the different institutional levels, in the overlapping of powers and competences of metropolitan governments, regions and State and in the tortuous decision-making processes intersecting these levels. That is where the causes of the difficulties that governments in large cities must face are to be found.

The complexity of the metropolitan area is not imposed 'from above', but it belongs to a process of institutional innovation. It is necessary to update the ruling mechanisms of urban and metropolitan areas since this is a truly national issue. After being neglected for a long time, the reality of metropolitan areas was the focal point of legislator's attention twice in Italy during a ten-year period; the first time in Law n. 142/1990 and after in Law 265/1999, then in the following Legislative Decree $267 / 2000$, which constituted the new consolidated text of the laws on the structure of local authorities, and finally in Constitutional Law n. 3/2001 which reformed Title V in part II of the Constitution of the Italian Republic.

Law 142/90 introduced the reform of local powers; above all, the model which had been broadly welcomed in the double level of land government was upheld; it had been previously used by the Provincial administration and the Municipality, intervening on their mutual competences in conformity with the new role they were meant to play. The law defined the financial autonomy of local authorities without providing for specific financing instruments for metropolitan cities, thus determining a greater and incisive financial responsibility of local governments' fiscal and planning policies. With the intent to pay a special attention to metropolitan cities, within a year Law $\mathrm{n}$. 436/1999 provided territorial delineation of metropolitan area by the regions as well as a re-organization of districts, provinces and municipalities. On the other hand, Law n. 265/1999 upgraded the initiative of municipalities and Regions, which were empowered to submit the establishment of metropolitan cities to government. Legislative Decree n. 267/2000 put into effect the proxy referred to in article 31 of Law 265/99, as well as the amendments of Law n. 142/90, thus replacing the consolidated text of the laws on the structure of local authorities. Article 22 produces in full the formulation of article 17 of 1990 Law; yet it adds that between the main municipality and the neighbouring population centres there must be "close territorial integrations"; thus, territory becomes an essential element for its identification. The innovation introduced by this decree concerns the implementing procedure. Should the metropolitan city not coincide with the territory of a province, either a new delimitation of provincial districts or the establishment of new provinces is implemented.

These provisions are in force; the metropolitan city is the new institution resulting from the municipal capital and from other municipalities linked to it by relations of territorial contiguity or by close economic integrations, from facilities to environmental features and socio-cultural relations.

\section{Establishment of the metropolitan city}

The working-out of a draft Statute for the territory, including the internal organization and the functions of the Municipalities involved, is ratified by their respective councils' resolution. 
The draft Statute is binding for the assembly of the local authorities concerned; within 180 days after its adoption, the proposal of establishing metropolitan cities is put to a popular referendum. Should the metropolitan city not coincide with the territory of the province, a new province district is implemented. The area of the city is considered as a territory of a new province, or "new body". In 2001, chapter V of the Constitution of the Italian Republic was modified by rewriting a lot of articles and by introducing new rules, among which article 114 of the Constitution."The Republic is composed of the Municipalities, the Provinces, the Metropolitan Cities, the Regions and the State".

These are autonomous entities having their own statutes, powers and functions in accordance with the principles laid down in the Constitution.

The competences are those that article 19 of Law n. 142/90 attributed to the respective functions of provinces and a series of local authorities, normally under the subordination of Municipalities, and among which the regional law should have identified the metropolitan area. In accordance with Law n. 267, these functions must be performed in the metropolitan area with a coordinated approach; article 24 "coordinated performance of functions" provides that the region, by previous agreement with the other coordinated institutions concerned, may define supra-municipal authorities for coordinated performance of functions of local administrations, through forms of cooperation and association, with which jointly exercising those functions that a variety of local authorities are able to perform.

The essential points of the reform of title $\mathrm{V}$ are broadly speaking: legislative function, administrative and financial function, fiscal federalism. Constitutional changes were put to a referendum and people expressed themselves in favour of the reform. It seems clear that in the new formulation of article 114 of the Constitution of the Italian Republic there is the outgrowing of a vertical hierarchical scheme, setting out the central state at its top and regions, provinces and municipalities in a graded form.

In April 2003 the Italian Council of Ministers approved a draft law. Loggia-Bossi, providing new amendments for title $\mathrm{V}$, second part of the Constitution of the Italian Republic, clearly overcame legislative competences between State and Regions; article 113 of the Constitution of the Italian Republic was integrated as follows «the establishment of the metropolitan city within a region is stated in accordance with the legal provisions of the State Law, on the initiative of the municipalities concerned, after consultation with the provinces and the Region concerned».

Moreover, for the city of Rome the special capital scheme was introduced, thus replacing article 114 paragraph $3^{\circ}$ «Rome is the capital of the Republic. Its status is regulated by State Law». Law Decree n. 35 of 14th March 2005 underlines investment priority needs for metropolitan areas and within it legislator recognized "Urgent measures in the framework of the Action Plan for economic, social and territorial development"; thus the Interministerial Committee on Economic Programming (CIPE) finances with priority actions included in the programme for strategic infrastructure (Law 443/2001), allocating a proportion of funding to underused areas. Practically financing depends on the European Union, on state or local funds, or on societies directly or indirectly referable to the State; access to finance depends on local authorities' capacity of political expression. The implementing process of title $\mathrm{V}$, resumed through the approval of government bill known as code of autonomies, drafted jointly by Minister for Regional Affairs and Local autonomies and Minister of the Interior, was passed by the Council of Ministers in January 2007.

\section{Metropolitan Government formation and action}

The regulation specifies that metropolitan cities will acquire the functions that previously belonged to the pre-existent Province, namely the so-called vast areas functions concerning their own territory, and the functions of metropolitan government to be defined by the state or by the regions according to their specific needs. In the new code it emerges that the main tasks of metropolitan cities should include local public service management strategy having an economic importance. Moreover, one must not overlook the fact that the metropolitan city should be understood in a broader sense, since it 
consists of resident and non-resident populations. What will happen to the metropolitan city is not quite clear if, in accordance with article 116 of the Constitution of the Italian Republic, regions receive (upon their request) jurisdiction in matters relating to the protection of the environment, an issue which - as everybody knows - finds in the metropolitan areas the greatest difficulties of intervention. The functions of metropolitan areas do not seem to be clearly expressed: a distinction between compulsory function (State), optional function (Regions), and experimental functions (defined by the State and by the Regions) as appropriate to their characteristics would have been more correct.

After the adoption of the Code of Autonomy, the Italian Minister of Economic Affairs presented the draft law on fiscal federalism (June 2007) with the government's delegation to regulate financial resources of regions and local authorities (article 119 of the Constitution of the Italian Republic).

The regulation intends to define a stable trim of territorial finance and it should complete the Code of Autonomies so that it might not only contain provisions in matters relating to financial resources but also introduce a safeguard rule resulting from greater burdens for public finances (contents and rules of financial coordination, financial principles of tax system coordination, financial relations between state and regions, local authorities' finance, financial relations between state and local authorities and between regions and local authorities). From then onwards various adaptation measures regarding the new metropolitan cities have been implemented.

\section{References}

[*] This paper is the product of the two authors' common reflection; however, A. Destefano supervised the paragraphs "Establishment of the metropolitan city" and "Metropolitan Government formation and action", M. Ferrara the paragraphs "The origins of metropolitan thought" and "A question of regulation".

[1] A. Sestini: Introduzione allo studio dell'Ambiente. Fondamenti di geografia fisica, Franco Angeli, Milano (2003), p. 201.

[2] A. Bruzzo, V. Ferri: La popolazione non residente nelle maggiori aree urbane e metropolitane italiane: $i$ risultati di una verifica empirica circa le implicazioni per $i$ bilanci dei Comuni coinvolti, Franco Angeli, Milano (2008), p. 20. 